日臨外会誌 $77 （ 8), 2106-2110,2016$

症例

ヘルニア囊内で内ヘルニアをきたし結腸皮膚瘻を生じた臍へルニアの 1 例

汐田総合病院外科

木村和孝皆川輝彦森田真理長谷部行健

症例は79歳, 女性. 現病歴：BMI36と肥満のある患者. 排便をしょうといきんだとこ ろ, 右側臍部から便が出たとのことで, 近医を受診し入院加療, 手術目的に当院紹介と なった。臍部に手拳大の膨隆を認め, 一部皮膚壊死を起こした部位より便汁の流出が認

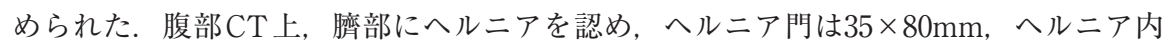
容は小腸, 大腸, および大網で, ヘルニア囊内にfree airを認めた. ヘルニア嵌頓に伴 う消化管穿孔の診断にて手術となった。手術は皮膚㾇の創を延長するように正中切開を 行った。ヘルニア囊を皮下より全周性に剥離し, 開放すると大網がヘルニア囊に癒着し ており, 大網の間隙から横行結腸が脱出し嵌頓, 穿孔していた. 小腸は虚血の所見なく, 臍ヘルニア自体による絞抳は認めなかった。 穿孔部位を切除し, end GIAを用いて functional end-to-endにて吻合した，污染創であるためメッシュは用いず，単閉鎖にて ヘルニア修復とした，術後経過は良好で20病日目に退院となった。

索引用語：臍へルニア, 破裂, 瘦孔

緒言

臍ヘルニアは，一度閉鎖した臍輪が後天的な臍部の 瘕痕組織進展により脆弱化し発症する比較的稀な疾患 であるが，臍ヘルニア内の大網裂孔ヘルニア嵌頓によ り結腸皮膚瘦をきたした極めてまれな症例を経験した ため報告する。

\section{症例}

患者：79歳, 女性.

主訴：腹部膨隆.

現病歴: 以前から臍部の膨隆を自覚していたが, 症 状がないため様子を見ていた，排便をしようといきん だところ, 腹部から便が出てきたとのことで近医を受 診し, 手術目的に当院紹介となった.

既往歴 : 変形性膝関節症.

手術歴：なし.

社会的背景：一人暮らしの高齢女性で, 滕痛を理由 に1日中ベッド上で過ごし，スナック菓子やチョコレ 一トなどを毎日繰り返し食べ, 訪問介護者に食事の買 い出しを依頼し，食事もべッド上で行うなど，健康的

2016年 3 月15日受付 2016年 6 月 2 日採用

〈所属施設住所〉

₹230-0001 横浜市鶴見区矢向 $1-6-20$
な生活は送れていなかった。

来院時現症：身長 $154 \mathrm{~cm}$, 体重 $85 \mathrm{~kg}$, BMI36, 体温 37.2 度, 血圧 $150 / 80 \mathrm{mmhg}$, 脈拍 85 回, 臍部に手拳大 の膨隆を認め, 臍部右側に腸管皮膚掼を認めた（Fig. 1)。腹部は軟で, 圧痛は認めなかった。

血液生化学所見：採血でWBC 8,082/ $\mu$ l, CRP 5.30 $\mathrm{mg} / \mathrm{dl}$ と軽度炎症反応の上昇を認めたが, その他異常 所見は認めなかった。

入院時腹部 CT 検査 : 正中臍部に $35 \times 80 \mathrm{~mm}$ 大のへ ルニア門を認め, ヘルニア内容は小腸, 大腸, 大網で, ヘルニア囊内および皮下にfree airを認めた（Fig. 2).

入院後経過：臍ヘルニア嵌頓，消化管穿孔の診断に て緊急手術施行した。

手術所見 : 皮膚瘦の創を延長するように正中切開を 行った。ヘルニア囊を皮下より全周性に剥離し, 瘦孔 部から切開すると大網がヘルニア囊内に癒着してお $り$, 大網の間隙から横行結腸が脱出し同部位に $20 \mathrm{~mm}$ 大の小さなヘルニア門があり, 嵌頓・循環不全により 穿孔していた，その他，小腸もヘルニア内に存在して いたが虚血の所見などもなく臍ヘルニアによる絞扼は 認めなかった，穿孔部位を切除し， end GIAを用いて functional end-to-endにて吻合後, 腹腔内 $1,000 \mathrm{ml}$ 洗 浄し, 閉腹した. 污染創であるためメッシュは用いず, 


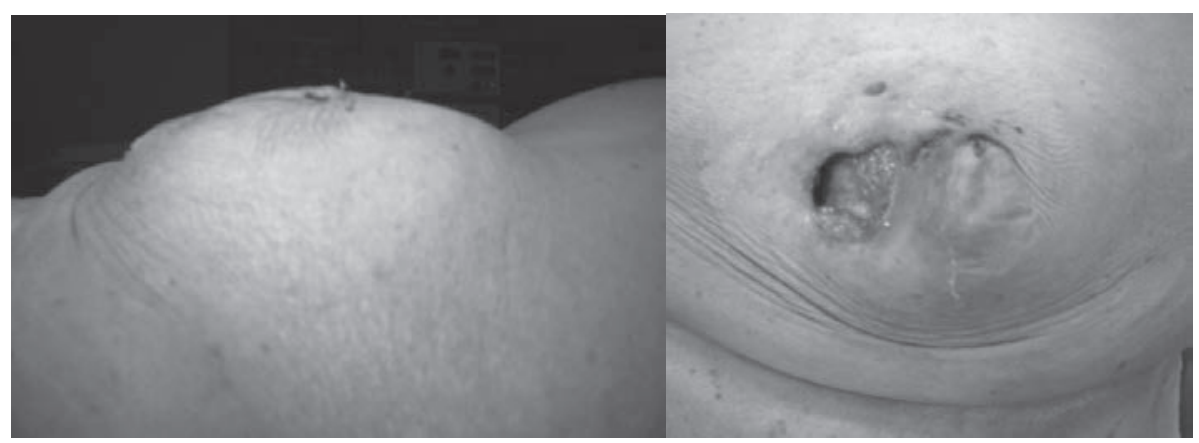

a

b

Fig. 1 来院時身体所見： $\mathrm{a}$ 手拳大の膨隆を認め, $\mathrm{b}$ 臍部右側に結腸皮膚瘦を認めた.
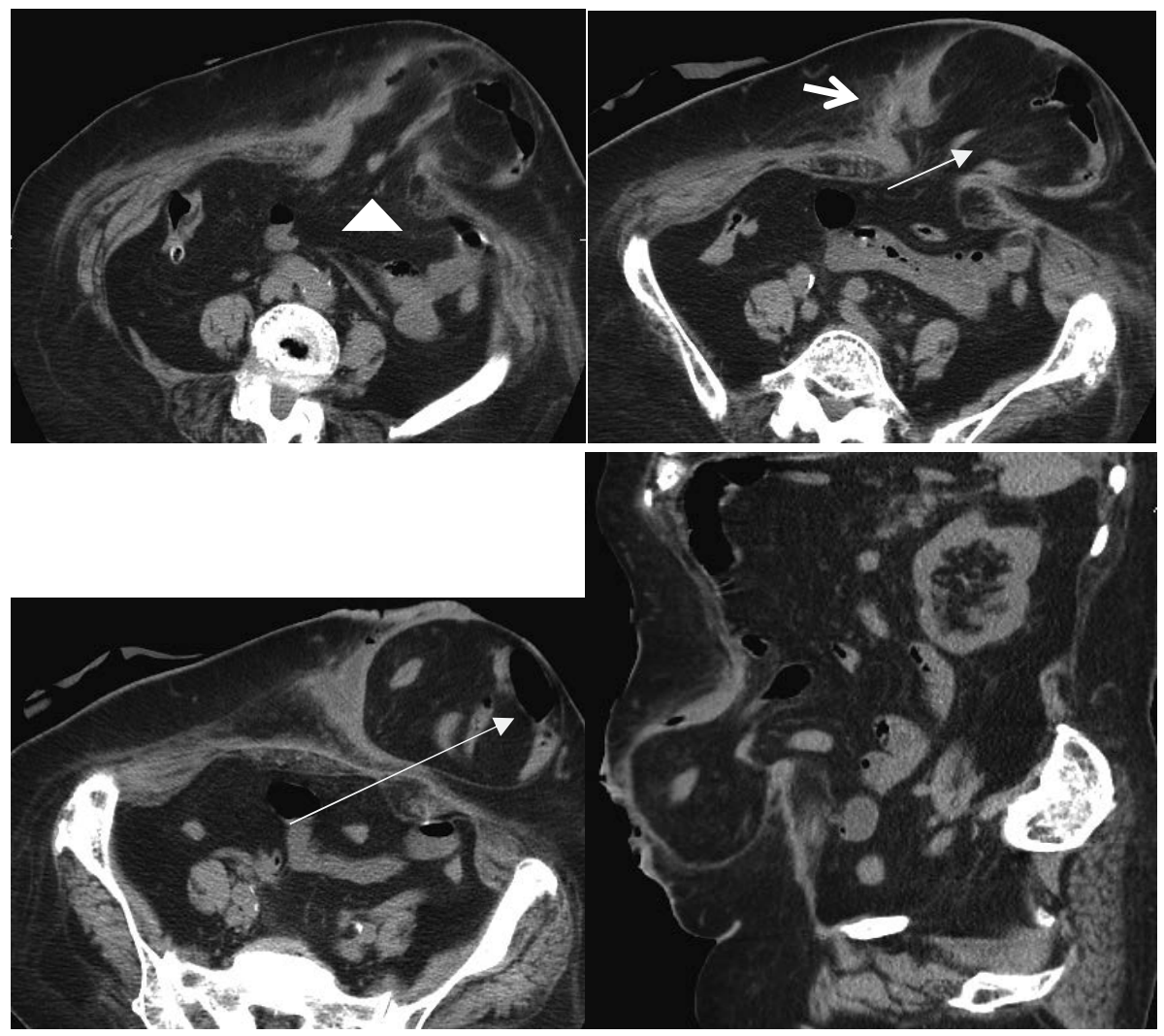

Fig. 2 腹部造影 CT : 臍部正中に $35 \times 80 \mathrm{~mm}$ 大のヘルニア門（ $\mathrm{a}$, 矢頭 $)$ を認め, ヘルニア内容 は大腸 (b, 太矢印) - 大網 ( b , 細矢印) - 小腸 ( $\mathbf{c}$, 長矢印) で, ヘルニア囊周囲に free air （b， c, d）を認めた.

\begin{tabular}{l|l}
$\mathrm{a}$ & $\mathrm{b}$ \\
\hline $\mathrm{c}$ & $\mathrm{d}$
\end{tabular}

1 バイクリルを用いて単純閉鎖にてヘルニア修復とし た (Fig. 3, 4).

術後経過：術後経過は良好で, 術翌日より飲水を開
始し, 術後 2 日目より食事摄取を開始した. 創部の改 善を待って, 20 病日目に退院となった。气の後 1 年間 再発を認めていない（Fig. 5). 


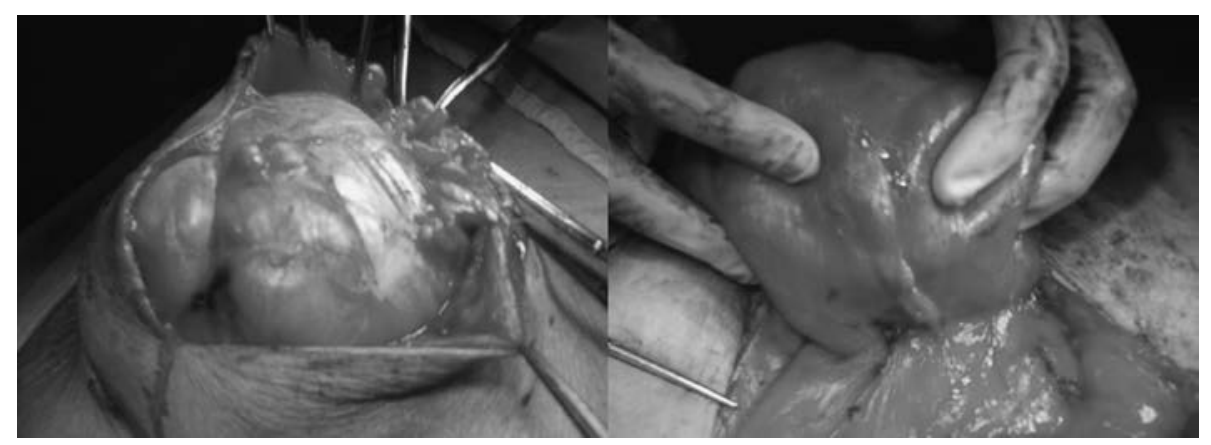

a

$\mathrm{b}$

Fig. 3 術中写真 1 ：皮膚瘦の創を延長するように皮膚切開を置き（a), 臍ヘルニアのヘルニア 門を確認（b ）。

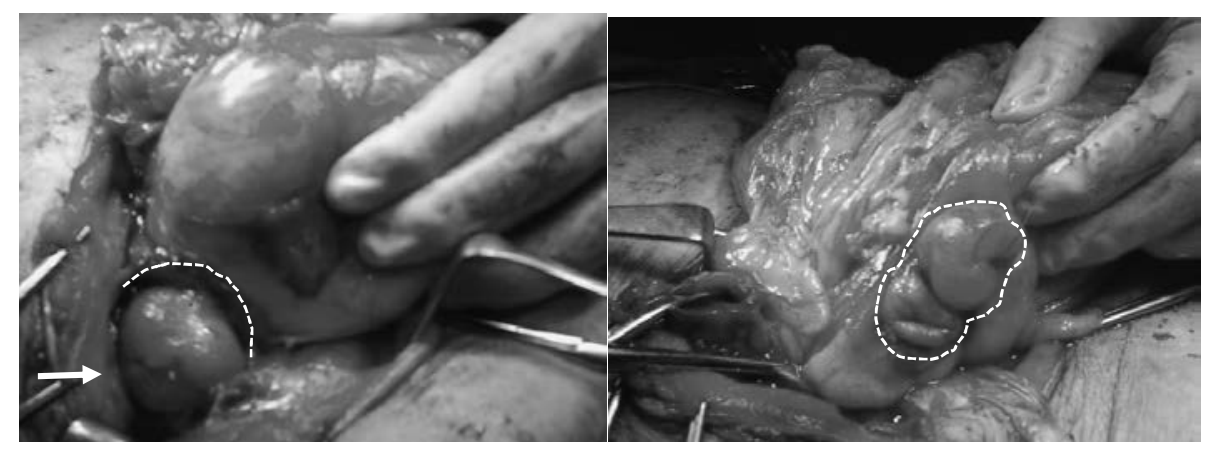

a

b

Fig. 4 術中写真 2 : ヘルニア囊内の大網裂孔による小さなヘルニア門（ $\mathrm{a}$, 点線）から大腸が脱 出し穿孔していた (a, 矢印).

ヘルニア囊を開放すると, 大網の間隙から大腸の脱出を認めた（ b，点線）.

\section{考察}

成人臍へルニアは, 先天的な臍輪の閉鎖不全に伴う 小児臍ヘルニアとは異なり, 腹腔内圧上昇因子に伴い, 一度閉鎖した臍輪が後天的な細部の瘏痕組織進展によ り脆弱化し再度開大することで発症するとされる1). そのため, 慢性的な腹圧上昇を伴う腹水を持つ患者や, 肥満・多産の中年女性に発症頻度が高いことが知られ ている11.

本邦での自然破裂の報告はまれであり，「臍へルニ ア・破裂・瘻孔」,「umbilical hernia $\cdot$ rupture $\cdot$ fistula」をkey wordに医学中央雑誌で1983年から2015年 までの33年間で検索しえた中で，臍へルニア破裂の症 例は自験例を含めて 9 例で2) 9)，本症例のように皮膚 瘦を形成した症例は, 横行結腸癌を内容とした成人臍 ヘルニアの 1 例5) と自験例を含めた，わずか 2 例であ った (Table 1).さらに, 本症例のように臍へルニ
ア内で内ヘルニア嵌頓を起こした症例の報告は本邦初 である. 臍へルニアでは, 他の腹壁・腹腔ヘルニアと 比べ 5 倍閉塞が起こりやすいとされている ${ }^{10)}$. 緊急手 術を必要とした腹部のヘルニアの中では, 臍ヘルニア が57\%を占め, 最も高いとする報告もある10). 今回の 症例検索では, 小腸穿孔が 1 例, 大腸穿孔が 2 例, 小 腸脱出・壊死が 2 例, 大網脱出・壞死が 1 例で, いず れも切除を要した. 残り 3 例は, 腹水漏出のみであっ たが，全例緊急手術が選択されている．臍ヘルニア修 復術式に関しては 7 例に直接縫合閉鎖が施行され， 2 例にメッシュによる修復が施行されていた，単閉鎖に よる臍へルニア修復術の再発率の $11 \%$ に対して, メッ シュを用いた術式では $1 \%$ と有意に低值とされ ${ }^{11)}$, へ ルニア門が $2 \mathrm{~cm}$ 以上の場合単閉鎖は推奨されていな い10). 本症例ではへルニア門が $3.5 \mathrm{~cm}$ であったが, 腸 管穿孔を伴っていたため, 単閉鎖による修復を施行し 


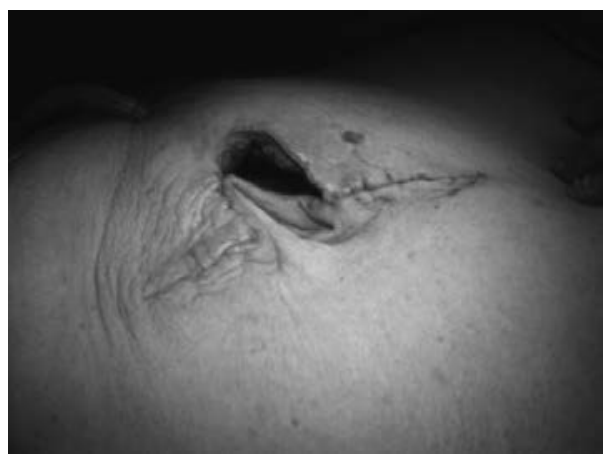

a

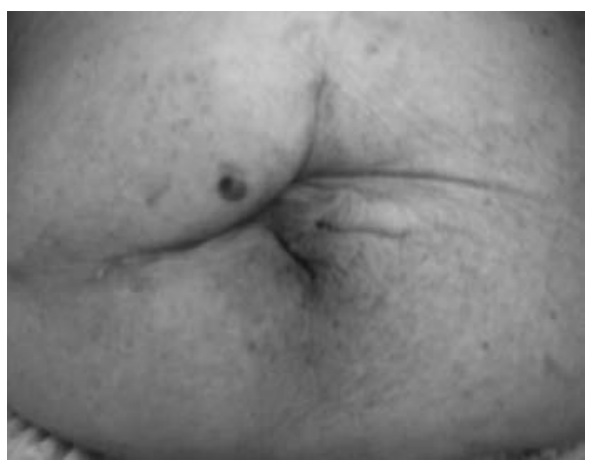

b

Fig. 5 術後写真 : 術直後の創部写真（a）ドレナージも兼ねて，完全には皮膚を閉鎖せず洗浄処 置を連日行った，退院前の創部写真（b ）洗浄処置のみで, 創部は感染なく閉鎖した.

Table 1 成人臍ヘルニア破裂の症例報告

\begin{tabular}{|c|c|c|c|c|c|c|c|}
\hline 著者 & 年 & 年齢 & 性別 & 併存疾患 & 腸管障害 & 脱出臓器 & 術式 \\
\hline 矢吹 & 1989 & 63 & 男 & 肝硬変 & - & - & 直接縫合 \\
\hline 小石 & 2003 & 81 & 女 & 肥満, 卵巣囊胞 & 小腸壊死 & 小腸 & 直接縫合 \\
\hline 池田 & 2005 & 54 & 男 & 肝硬変 & - & - & メッシュ \\
\hline 西村 & 2006 & 68 & 男 & 横行結腸癌 & 大腸穿孔 & - & 直接縫合 \\
\hline 絹田 & 2010 & 54 & 男 & 肝硬変 & - & 大網 & 直接縫合 \\
\hline 松野 & 2011 & 63 & 女 & 肥満 & 小腸穿孔 & 小腸 & 直接縫合 \\
\hline 久保 & 2012 & 50 & 男 & 肝硬変 & - & - & メッシュ \\
\hline 加藤 & 2013 & 88 & 女 & なし & 小腸壊死 & 小腸 ～～～～～ & 直接縫合 \\
\hline 自験例 & 2016 & 79 & 女 & 肥満 & 大腸穿孔 & 小腸, 大網, 大腸 & 直接縫合 \\
\hline
\end{tabular}

た. 破裂以前に皮膚症状を伴う症例の報告は 4 例で, 色調変化・糜爛・潰瘍の所見が 2 例で, 結腸皮膚瘦が 2 例であった，本症例では，結腸穿孔を伴っており， 結腸皮膚㾞の状態に陥っていた。皮膚障害の機序とし ては, 臍へルニア部の皮膚が菲薄化したことから, 局 所的な循環障害に至ると考えられている1213). また, 嵌頓阻血状態でなくとも圧上昇により腸管が穿孔する ことがあり, 排便・排尿・起床といった程度の圧上昇 でもへルニア存在時には腸管穿孔の誘因となりうると されている14).

本症例では腹膜炎の状態には至っておらず, 臍へル ニア内の大網や小腸に壊死所見がなく, 壊死・穿孔部 位が大網の間隙から脱出した横行結腸に限られていた ことを考えると, 臍ヘルニア内で大網裂孔ヘルニア嵌 頓を起こしたと推測される，また，臍へルニアによる 皮膚の菲薄化から皮膚障害を認めているところに, 大 網裂孔ヘルニア嵌頓による大腸穿孔を起こし, 皮膚瘻 を形成に至り,さらに排便時のいきみによる急激な圧 上昇から皮膚の破綻をきたしたと考えられた。 大網裂
孔の成因には先天的な要因のほか, 瘦せや加齢による 大網萎縮や脆弱化といった要因が挙がるが, 薄くて長 いという解剖学的特徵から栄養静脈の梗塞や虚血が生 じやすいことが指摘されている15)16). 今回の症例では, 臍ヘルニア内の大網に慢性的な虚血を繰り返したこと で大網に裂隙を生じ, 内ヘルニアを起こしたに至った と考えた.

今回の症例の社会的背景として, 一人暮らしの高齢 女性で, 健康的な生活は送れていなかった。病識にも そしかったことが予想され，慢性的な経過を辿ったと 考えれば，早期受診の機会を作ることができていれば 腸管切除を避けることができたのかもしれない. 最近 では高齢者の一人暮らしが増えており, 早期受診の機 会に加え, 生活習慣の改善や病気に対する啓蒙なども 同時に行っていく環境づくりも必要だと考えた.

\section{結 語}

今回われわれは，臍へルニア内で内ヘルニアをきた し，結腸皮膚瘻を伴った極めてまれな 1 例を経験した ため報告した。 


\section{文献}

1) Velasco MA, Garcia-Urena M, Hidalgo M, et al : Current concepts on adult umbilical hernia. Hernia $1999 ; 3: 233-239$

2）矢吹清一: 大量腹水による脐ヘルニア破裂の 1 例. 日臨外会誌 $1989 ; 50 ： 2264-2266$

3）池田宏国, 辻 和宏, 三谷英信他：肝硬変に伴う 大量腹水による臍ヘルニア破裂の 1 例. 日臨外会 誌 $2005 ; 66: 519-522$

4）松野高久, 加納久雄, 木田和利他：2 所の腸管 脱出, 嵌頓壊死を起こした巨大臍へルニアの 1 例. 日大医誌 $2011 ; 70: 208-211$

5）西村 真, 片岡順三, 矢永勝彦 : 横行結腸癌を内 容とした成人臍ヘルニアの 1 例. 日臨外会誌 $2006 ; 67: 919-923$

6) 絹田俊爾, 輿石直樹, 松村 優他 : 難治性腹水に より大網の腹壁外脱出を伴う成人臍ヘルニア破裂 をきたした 1 例。 日臨外会誌 $2010 ； 71 ： 221$ 224

7）加藤健宏, 寺崎正起, 岡本好史 : 小腸の体外脱出 をきたした臍ヘルニア破裂の 1 例. 日本腹部救急 医会誌 $2013 ; 33: 1067-1070$

8）小石健二, 楠原清史, 柳生隆一郎他：腸管の腹壁 外脱出を見た成人臍ヘルニア囊破裂の 1 例. 日外 科系連会誌 $2003 ; 28 ： 903-906$
9）久保 徹, 大草 康 : 肝硬変に伴う難治性腹水か ら発症した成人臍ヘルニア破裂の 1 例. 日臨外会 誌 $2012 ; 73: 1017-1020$

10) Bittner R, Bingener-Casey J, Dietz U : Guideline for laparoscopic treatment of ventral incisional abdominal wall hernia. Surg Endosc $2014 ; 28$ : $2-29$

11) Ahmed A, Stephen G, Ukwenya Y : Spontaneous rupture of umbilical hernia in pregnancy: a case report. Oman Med J $2011 ; 26: 285-287$

12) Good DW, Royds JE, Smith MJ, et al : Umbilical hernia rupture with evisceration of omentum from massive ascites : a case report. J Med Case Rep $2011 ; 5: 170$

13) Arroyo A, Garcia P, Perez F, et al : Randomaized clinical trial comparing suture and mesh repair of umbilical hernia in adults. Br J Surg 2001 ; $88: 1321-1323$

14）池口正英, 金子徹也, 田村英明他 : 鼠径, 大腿へ ルニアによる消化管穿孔の臨床検討。鳥取医誌 $1986 ; 14: 57-60$

15）重政 有, 清水輝久: 大網裂孔ヘルニアによる絞 扼性イレウスの 1 例. 臨外 $2002 ; 57: 702-705$

16）坂下克也, 寺岡 均, 豊川貴弘他 : 非典型的な嵌 入様式を示した大網裂孔ヘルニアの 1 例. 日臨外 会誌 $2012 ; 73: 2444-2447$

\title{
A CASE OF UMBILICAL HERNIA IN WHICH INTERNAL HERNIA OCCURRED IN THE HERNIA SAC, CAUSING A COLON SKIN FISTULA
}

\author{
Kazutaka KIMURA, Teruhiko MINAGAWA, Mari MORITA and Yukitake HASEBE \\ Department of Surgery, Ushioda General Hospital
}

The case was a 79-year-old female patient. She presently is obese, with a body mass index of 36 . When she was straining to defecate, she found the stool coming out from the right umbilical region. Thus, she visited the nearest clinic and was referred to our hospital for hospitalization and treatment. We found a fist-sized bulge at the umbilical region and mushy feces draining out of the part where skin necrosis had occurred. Abdominal computed tomography revealed a hernia in the umbilical region, with an orifice of $35 \times 80 \mathrm{~mm}$. The hernia content covered the small intestine, the large intestine, and the greater omentum, and free air was found to exist in the hernia sac. Based on the diagnosis of bowel perforation accompanying hernia incarceration, we performed the following surgery. We made a median incision, to extend the surgical wound of the skin fistula. We circumferentially detached the hernia sac under the skin to open the space and found that the greater omentum was adhered to the hernia sac, and that the transverse colon was prolapsed from a gap in the greater omentum and was incarcerated and perforated. The small intestine did not show any sign of ischemia, and strangulation by the umbilical hernia itself was not observed. We excised the perforated part and made a functional end-to-end anastomosis by using an end GIA. Due to the contaminated wound, we did not use meshes and finished the hernia repair by adopting a simple closure. Post-operative conditions were good, and the patient was discharged on day 20.

Key words : umbilical hernia, rupture, fistula 